\title{
TRAINING OF TRAINERS (TOT) KETRAMPILAN UNTUK DIDESEMINASIKAN SEBAGAI ALTERNATIF MENAMBAH PENGHASILAN IBU-IBU RUMAH TANGGA
}

\author{
Eko Tri Rahardjo \\ Jurusan Geografi Fakultas Ilmu Sosial Universitas Negeri Jakarta
}

\begin{abstract}
ABSTRAK
Pelaksanaan KKN di perdesaan, memberi peluang bagi masyarakat untuk memperoleh ketrampilan dalam rangka menambah penghasilan. Dengan adanya mahasiswa KKN memberi ketrampilan, maka masyarakat akan berpeluang mendapatkan ketrampilan secara gratis yang pada akhirnya dapat memperoleh peluang mecari penghasilan tambahan.

Namun demikian tidak semua mahasiswa peserta KKN mempunyai ketrampilan yang dapat diberikan ke masyarakat berupa ketrampilan yang menghasilkan "sesuatu yang dapat dijual". Oleh karena itu kegiatan ini memberi bekal kepada mahasiswa calon peserta KKN untuk menjadi trainers di tempat mereka ber KKN nanti.

Melalui pelatihan TOT bagi mahasiswa calon peserta KKN UNJ yang dideseminasikan kepada para ibu-ibu di lokasi KKN maka diharapkan diperoleh alternatif menambah penghasilan, dengan mengikuti pelatihan tanpa mereka harus mengeluarkan biaya.
\end{abstract}

Kata Kunci : TOT, KKN, mahasiswa

\section{PENDAHULUAN}

A. Analisis Situasi

Pendidikan dan hidup layak merupakan hak seluruh bangsa Indonesia, pendidikan dapat dijangkau melalui proses pembelajaran, dan pembelajaran tidak dibatasi oleh waktu dan usia. Belajar dan pembelajaran berlangsung sepanjang hayat sejauh hal itu diperlukan. Manusia belajar sesuai dengan kebutuhannya. Tujuan pembelajaran yang mencakup belajar afeksi, belajar kognisi dan belajar ketrampilan semua membawa manfaat sesuai dengan porsinya. Masing-masing tujuan pembelajaran tersebut akan memberikan kontribusi kepada kehidupan individu sesuai dengan kapasitas dan kebutuhannya.

Di kehidupan sekitar kita, tidak semua anggota masyarakat dapat menempuh pendidikan sampai jenjang tinggi. Terdapat sekelompok masyarakat yang hidup dengan bekal pendidikan minimum. Hal ini disebabkan karena banyak hal yang antara lain ketiadaan biaya, waktu dan lainnya yang intinya adalah pada ketiadaan kesempatan. Kondisi seperti ini juga terjadi di banyak tempat di lokasi KKN mahasiswa UNJ, dimana terdapat sekelompok masyarakat dengan ias 70 meningkatkan pendidikan dan ketrampilanya yang dapat meningkatkan penghasilan dan taraf hidup mereka. Bekal ijasah yang rendah dan ketiadaan biaya serta kurangnya kemampuan atau ketrampilan, berakibat mengurangi kesempatan untuk maju dan menjadi salah satu kendala kemajuan kehidupan ekonomi mereka.

Sehubungan dengan hal di atas maka diperlukan suatu upaya yang secara riil dapat dilakukan dan berdampak langsung terhadap kemampuan mereka dalam meningkatkan kehidupan perekonomiannya. Salah satu upaya tersebut adalah dengan memberikan ketrampilan tambahan dan memberikan hasil yang nyata, cepat dan langsung dapat dimanfaatkan dan dirasakan hasilnya

Di lain pihak dengan pelaksanaan KKN di perdesaan, memberi peluang bagi masyarakat untuk memperoleh ketrampilan dalam rangka menambah penghasilan. Dengan adanya mahasiswa KKN memberi ketrampilan, maka masyarakat akan berpeluang mendapatkan ketrampilan secara gratis yang pada akhirnya dapat memperoleh peluang mecari penghasilan tambahan. Namun demikian tidak semua mahasiswa peserta KKN mempunyai ketrampilan yang dapat diberikan ke masyakat Jurnal Sarwahita Volume 12 No. 2 
berupa ketrampilan yang menghasilkan "sesuatu yang dapat dijual”. Oleh karena itu kegiatan ini memberi bekal kepada mahasiswa calon peserta KKN untuk menjadi trainers di tempat mereka ber KKN nanti.

\section{B. Perumusan Masalah}

\section{Identifikasi Masalah}

Berdasarkan analisis situasi yang telah diuraikan, maka masalah yang dapat diidentifikasikan adalah sebagai berikut:

a. Banyak masyarakat di lokasi KKN yang taraf perekonomianya relatif rendah.

b. Di masyarakat yang jenjang pendidikannya rendah sukar meningkatkan ketrampilan dan pendapatanya.

c. Masyarakat di lokasi KKN banyak yang mengalami kendala dalam meningkatkan jenjang pendidikan karena alasan ekonomi dan kesempatan.

d. Diperlukan ketrampilan tambahan untuk mendapatkan peluang meningkatkan perekonomian dan kesejahteraan.

e. Perekonomian yang terbatas ini membatasi masyarakat dalam memperoleh pendidikan dan ketrampilan.

f. Diperlukan upaya untuk memberikan ketrampilan tanpa mereka harus berhenti bekerja atau mencari nafkah dan tanpa mengeluarkan biaya.

g. Salah satu upaya tersebut adalah melalui pemberdayaan mahasiswa KKN sebagai instruktur yang telah dibekali berbagai ketrampilan.

h. Untuk menjadi instruktur maka mahasiswa calon peserta KKN diberi pelatihan sebagai instruktur melalui kegiatan TOT ketrampilan.

\section{Rumusan Masalah}

Dari berbagai permasalahan yang dapat diidentifikasi, maka masalah yang dirumuskan dalam program ini adalah: melalui pelatihan TOT bagi mahasiswa calon peserta KKN UNJ yang dideseminasikan kepada para ibu-ibu di lokasi KKN maka diharapkan diperoleh alternatif menambah penghasilan. tanpa mereka harus mengeluarkan biaya, sehingga diperoleh peluang mendapatkan penghasilan tambahan.

\section{B. Tujuan Kegiatan}

Tujuan dari kegiatan ini dapat diuraikan sebagai berikut:

1. memberikan ketrampilan tambahan membuat berbagai barang kerajinan dengan bahan yang murah dan mudah didapatkan.

2. memberikan peluang meningkatkan pendapatan dengan berbagi pengalaman dengan instruktur sekaligus sebagai pengrajin.

3. menumbuhkan rasa percaya diri kepada para mahasiswa calon peserta KKN

4. meningkatkan sinergi dan kinerja, dengan kegiatan ini para peserta bKKN diharapkan menjadi lebih intens dalam komunikasi dengan masyarakat di lokasi KKN.

\section{Manfaat Kegiatan}

1. Memberikan ketrampilan tambahan bagi mahasiswa

2. Memberi ketrampilan tambahan bagi ibu-ibu di lokasi KKN

3. Memberikan peluang meningkatkan pendapatan.

4. Menumbuhkan rasa percaya diri mahasiswa calon peserta KKN

5. Meningkatkan sinergi dan kinerja.

6. Menambah suksesnya pelaksanaan KKN UNJ

7. Menambah nama baik UNJ di masyarakat lokasi KKN

\section{KAJIAN PUSTAKA}

\section{A. Ketrampilan dan Pendapatan}

Pendapatan yang dimaksud dalam kegiatan ini adalah penghasilan yang didapat seseorang dari hasil bekerja atau mengasilkan produk tertentu. Menurut Safir Senduk (2000), penghasilan seseorang dipengaruhi oleh faktorfaktor : pendidikan, pekerjaan, umur, harta, tempat tinggal, keberuntungan, bakat, kerjakeras, koneksi dan diskriminasi.

1. Pendidikan, orang yang berpendidikan tinggi cenderung menghasilkan banyak uang, hal ini menyebabkan orang 
akan berpenghasilan tinggi setelah menempuh pendidikan tinggi. Namun demikian yang benar adalah bahwa pendidikan bisa membantu seseorang untuk memperoleh penghasilan tinggi. Namun demikian terdapat potensi bahwa orang berpendidikan tinggi berpeluang lebih besar karena umumnya memiliki wawasan yang lebih luas.

2. Pekerjaan, orang yang pekerjaanya menggunakan pikiran biasanya lebih banyak menghasilkan uang dibandingkan dengan orang yang pekerjaanya menggunakan tenaga.

3. Umur, orang yang berumur lebih tua biasanya mendapatkan penghasilan lebih tinggi dibandingkan yang usianya lebih muda karena faktor pengalaman dan lama bekerja.

4. Harta, kaitan harta dengan penghasilan ialah bahwa seseorang bisa saja memiliki investasi sehingga dapat menambah penghasilan selain dari upah.

5. Tempat tinggal, standar gaji dan upah serta biaya hidup dapat memengaruhi perbedaan penghasilan walaupun dalam pekerjaan dan level yang sama tetapi beda tempat tinggal, misalnya beda kota atau di kota dengan kota lain yang beda peraturan.

6. Keberuntungan, faktor ini tidak dapat diprediksi tetapi tetap menjadi variabel yang dipertimbangkan, misalnya fluktuasi perusahaan menentukan bonus karyawan.

7. Bakat, bakat menentukan mutu pekerjaan sehingga dapat memengaruhi penghasilan seseorang.

8. Kerja Keras, kerja keras merupakan salah satu faktor yang menentukan produktifitas, selain dari promosi jabatan.

9. Koneksi, koneksi dapat menentukan penghasilan. Misalnya dengan koneksi mendapatkan penghasilan sampingan atau mendapat tambahan pekerjaan yang menghasilkan uang. menyangkut gender atau kesukuan. Misalnya pria dan wanita bekerja dalam level yang sama tetapi pria digaji lebih tinggi, sama-sama sebagai konsultan tetapi konsultan asing digaji lebih tinggi.

Sehubungan dengan uraian di atas maka yang dapat diupayakan untuk meningkatkan penghasilan pada masyarakat sebagai orang yang berpendidikan rendah, dan berharta tidak banyak, serta tempat tinggal yang kurang kondusif untuk mencari tabahan, caranya adalah dengan mengoptimalkan keberuntungan, bakat, kerjakeras, dan melalui koneksi yang legal. Mengoptimalkan keberuntungan dapat dilakukan dengan memberikan bekal ketrampilan sehingga memperoleh peluang lebih banyak, sedangkan bakat adalah diupayakan mengoptimalkan bakat dengan memberikan berbagai macam ketrampilan sehingga dimungkinkan untuk dipilih sampai akhirnya muncul salah satu bakat yang terpendam dan dapat dioptimumkan, kerja keras dapat diupayakan melalui etos kerja yang meningkat.

Adapun koneksi yang legal maksudnya adalah memberikan perhatian khusus dengan memilih secara sengaja kepada mereka yang benar-benar membutuhkan untuk diberikan peluang yang lebih besar.

\section{B. Metode Pembelajaran Ketrampilan}

Dalam proses pembelajaran, banyak sekali metode dan media yang dapat dipergunakan. Menurut Edgar Dale proses pembelajaran dengan cara mengalami sendiri akan mempunyai dampak yang lebih baik dibandingkan dengan apabila sekedar mendengarkan. Pada gambar di bawah ini ditunjukan tentang efektifitas pengalaman belajar. Bagian paling atas dari kerucut ini adalah bagian yang paling sempit memberikan kontribusi pengalaman belajar, sedangkan bagian paling bawah menunjukan pengalaman belajar yang hasilnya paling luas. (Edgar Dale dalam Oemar Hamalik, 1982). 


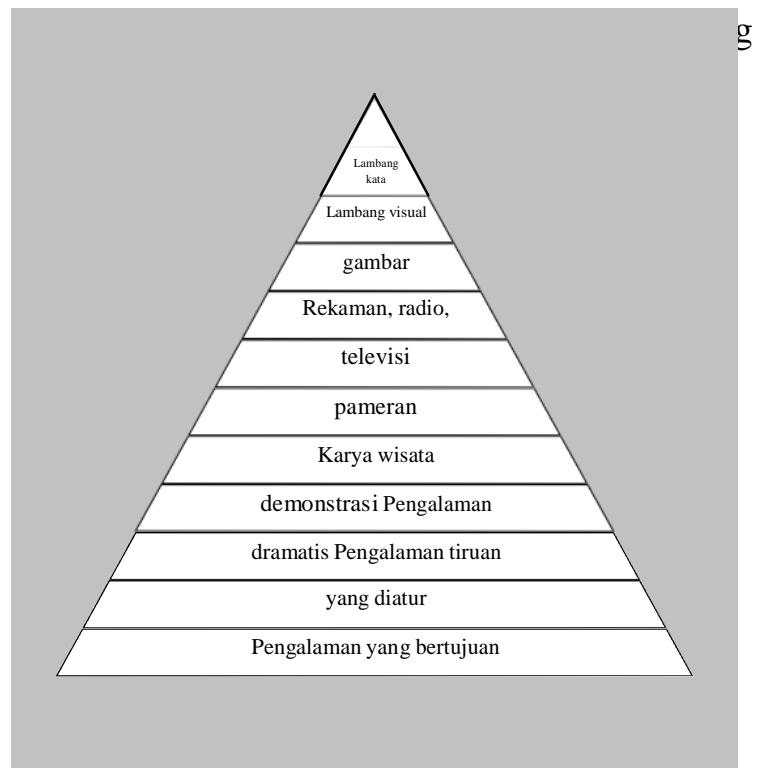

Gambar 1. Diagram efektifitas pengalaman belajar (Edgar Dale dalam Oemar Hamalik, 1976)

Berdasarkan pada gambar di atas terlihat bahwa pembelajaran ketrampilan akan baik jika diberikan secara langsung melibatkan aktivitas peserta. Sementara itu penyerapan informasi sehingga menjadi suatu hasil belajar juga mengalami suatu proses belajar. Proses belajar dikatakan baik apabila peserta mampu

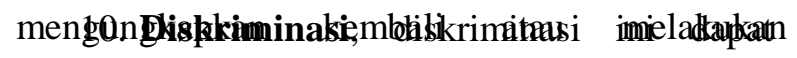
kembali apa yang telah diajarkanya. Dalam hal ini maka suatu hasil yang berupa produk merupakan manifestasi dari hasil pengung-kapan kembali apa yang dipelajari sebelumnya.

Dalam revisi teori Bloom tentang tujuan pembelajaran, Lorin W. Anderson dan David R. Krathwohl membuat taksonomi pembelajaran meliputi mengingat, memahami, mengaplikasikan, menganalisis, mengevaluasi dan mengkreasi.

Berdasarkan taksonomi di atas, apabila seseorang diberi pelajaran tertentu maka hasil akhirnya adalah menciptakan atau mempunyai suatu kreasi atau kemampuan mencipta sesuatu. Dalam hal ketrampilan membuat produk maka dapat dikategorikan sebagai pengetahuan faktual yang nyata tampak, dapat dilihat, dipegang dan dirasakan, sehingga hasil akhir dari bahan mentah dapat dicipta menjadi sesuatu yang bernilai lebih tinggi. Dari uraian ini jika kita memandang belajar melalui jalur ranah psikomotor, maka menurut Dave (1967) proses belajar dapat berjalan melalui langkah sebagai berikut:

\begin{tabular}{|l|l|l|l|l|}
\hline PENIRUAN & PENGGUNAAN & KETEPATAN & PERANGKAIAN & NATURALISASI \\
\hline $\begin{array}{l}\text { Meniru gerak } \\
\text { yang diamati } \\
\text { atau diajarkan }\end{array}$ & $\begin{array}{l}\text { Menggunakan } \\
\text { konsep untuk } \\
\text { melakukan gerak }\end{array}$ & $\begin{array}{l}\text { Melakukan gerak } \\
\text { dengan teliti dan } \\
\text { benar }\end{array}$ & $\begin{array}{l}\text { Merangkaikan } \\
\text { berbagai gerakan } \\
\text { secara } \\
\text { berkesinambungan }\end{array}$ & $\begin{array}{l}\text { Melakukan gerak } \\
\text { secara wajar dan } \\
\text { efisien }\end{array}$ \\
\hline
\end{tabular}

Untuk selanjutnya menurut Aida Idris (1982 / 1983) seseorang akan lebih berhasil belajar bila yang dipelajarinya itu bertalian dengan apa yang diperlukannya dalam kehidupan sehari-hari, yang berarti bahwa ia mengetahui secara jelas tujuan belajarnya. Agar tercapai keberhasilan belajarnya, faktor minat pun harus diperhitungkan. Minat seseorang terhadap apa yang dipelajarinya merupakan salah satu faktor yang memungkinkan konsentrasi belajarnya. Karena ia menaruh minat terhadap apa yang dipelajarinya itu maka akan timbul padanya kegairahan belajar, sehingga ia giat belajar. Oleh karena minat itu perlu ditimbulkan, dan minat belajar itu timbul apabila terdapat hubungan antara orang yang belajar dan yang dipelajarinya.

Berdasarkan uraian di atas, berarti bahwa pada seseorang itu harus ada berbagai kemampuan sehubungan apa yang dipelajarinya, seperti menghargai, memahami, menikmati, dan menggunakan apa yang dipelajarinya itu. Menurut Dale (dalam Oemar Hamalik, 1976) pengalaman langsung atau keterlibatan langsung akan mempengaruhi memori dalam pembelajaran. Sehubungan dengan hal tersebut secara teoritis metode pembelajaran langsung mempunyai konstribusi yang baik dalam proses pembelajaran. 


\section{MATERI DAN METODE}

\section{A. Metode Pemecahan Masalah}

Kegiatan terdiri dari $90 \%$ praktik dan sisanya berbagi pengalaman tentang cara mendapatkan bahan, prosesing dan peluang pemasaranya. Sesi satu display beberapa contoh barang kerajinan yang sudah dibuat dan akan dibuat.
Sesi kedua demonstrasi pembuatan dan langsung praktik dengan bahan yang disediakan. Peserta diminta mencoba mempraktekan yang diajarkan dan meneruskan jika belum jadi, atau bagi yang sudah jadi atau bisa membuat diminta untuk mengembangkan model lain.

Kegiatan ini direncanakan meliputi 3 sesi dengan jadwal sebagai berikut:

\begin{tabular}{|c|l|l|l|}
\hline Sessi ke & \multicolumn{1}{|c|}{ Materi Kegiatan } & Nara Sumber & Waktu \\
\hline 1. & $\begin{array}{l}\text { Membuat gelang dan asesories } \\
\text { dengan bahan manik-manik. }\end{array}$ & Pengrajin & 1 x pertemuan \\
\hline 2. & $\begin{array}{l}\text { Membuat gelang dengan manik- } \\
\text { manik berkawat. }\end{array}$ & Pengrajin & 1 x pertemuan \\
\hline 3. & $\begin{array}{l}\text { Membuat gelang dengan macam- } \\
\text { macam kombinasi. }\end{array}$ & Pengrajin & 1 x pertemuan \\
\hline
\end{tabular}

Jadwal kegiatan di atas dapat lakukan perubahan sesuai dengan kondisi dan kebutuhan peserta.

\section{B. Realisasi Pemecahan Masalah}

Pemecahan masalah dilakukan dalambentuk pelatihan pengenalan bahan, pembuatan berbagai barang kerajinan, penggalian ide inovatif, dengan memancing ide dari para peserta untuk memanfaatkan bahan sederhana dengan cara berpikir sederhana namun kreatif.

Melalui kegiatan pengabdian kepada masyarakat ini diharapkan akan memberikan ketrampilan yang dapat dimanfaatkan untuk mencari tambahan pendapatan.

Kegiatan ini bermanfaat bagi peserta untuk memperoleh materi pembuatan berbagai barang kerajinan. Dengan pelatihan ini peserta mendapat manfaat contoh dan ide pembuatan berbagai kerajinan, sehingga diharapkan mereka dapat mengembangkan inspirasinya untuk membuat sendiri, menjadi inovatif dan memanfaatkanya untuk mencari tambahan pendapatan setelah ikut pelatihan ini.

Pelatihan ini sifatnya pemberian motivasi bahwa dengan sedikit kreativitas, inovasi, dan kemauan, seseorang dapat membantu dirinya sendiri mendapatkan pendapatan lebih, dengan cara membuat berbagai kerajinan hasil kreatifitasnya.
Manfaat seperti tersebut di atas berlaku bagi mahasiswa sebagai calon trainers maupun bagi masyarakat sebagai peserta training dan pemangguna atau pemanfaat langsung ketrampilan yang diberikan.

\section{Khalayak Sasaran}

Sasaran dalam kegiatan ini adalah mahasiswa calon peserta KKN Universitas Negeri Jakarta ditargetkan 15 orang peserta. Kegiatan ini dilaksanakan pada hari kerja di luar jam kuliah atau pada saat istirahat. Instruktur diambil dari para pengrajin yang telah berpengalaman dalam pembuatan dan pemasaranya.

\section{Waktu dan Tempat Kegiatan}

Kegiatan dimulai dengan penyusunan proposal pada bulan Februari 2015 dan direncanakan selesai sebelum bulan Agustus 2015, tepatnya sebelum para mahasiswa diberangkatkan ke lokasi KKN. tempat direncanakan di Gedung LPM - UNJ dengan maksud supaya para mahasiswa tidak meninggalkan tempat tugas dan tidak usah mengeluarkan biaya transportasi. 
Jadwal kegiatan disusun sebagai berikut:

\begin{tabular}{|c|c|c|c|c|c|c|}
\hline \multirow{2}{*}{ No } & \multirow{2}{*}{ KEGIATAN } & \multicolumn{5}{|c|}{ BULAN } \\
\hline & & FEB & MAR & MEI & JULI & AGUS \\
\hline 1 & $\begin{array}{l}\text { Penyusunan } \\
\text { Proposal }\end{array}$ & & & & & \\
\hline 2 & $\begin{array}{l}\text { Pengajuan } \\
\text { Proposal }\end{array}$ & & & & & \\
\hline 3 & $\begin{array}{l}\text { Kegiatan } \\
\text { Pelatihan }\end{array}$ & & & & & \\
\hline 4 & $\begin{array}{l}\text { Penyusunan } \\
\text { Laporan }\end{array}$ & & & & & $\mathrm{XX}$ \\
\hline
\end{tabular}

\section{HASIL DAN PEMBAHASAN}

\section{A. Pelaksanaan Kegiatan}

Kegiatan telah dilaksanakan dengan lancar pada hari Jum'at, tanggal 25 Mei 2015, jam 13.00 - 15.30 di LPM UNJ. Kegiatan diikuti oleh 35 orang mahasiswa. Kegiatan diawali dengan pembukaan oleh Ketua Tim yang menyatakan tentang maksud dan tujuan dari kegiatan ini. Kemudian dilanjutkan dengan sambutan Ketua LPM sekaligus membuka kegiatan.

Untuk selanjutnya pelaksanaan dipandu oleh tiga orang instruktur yaitu:

1. Ibu Budi Astuti

2. Ibu Pirmantiningsih

3. Ibu Ria

Peserta dibagi menjadi tiga kelompok, masingmasing kelompok dipandu oleh satu instruktur.

Peserta dibagikan bahan, kemudian diberi pejelasan tentang:

1. Nama bahan, jenis bahan, masingmasing harganya dan tempat pembelianya.

2. Contoh bentuk-bentuk yang sudah jadi dan variasinya serta kemungkinan pengembangan ide-ide yang dapat dilakukan.

3. Harga jual, kemasan dan pangsanya, seperti untuk dijual eceran, dijual di konter khusus, untuk souvenkir hajatan seperti pernikahan, sunatan dsb.

Selanjutnya peserta diajarkan membuat kerajinan dengan langsung praktik, bagi mahasiswa yang telah selesai langsung diajarkan membuat kerajianan lainya. Bagi mahasiswa yang telah selesai diberikan tambahan bahan untuk praktik pengembangan di rumah masingmasing.

Pada bagian akhir kegiatan dilakukan evaluasi terhadap kerapihan hasil kerja dan dibenahi serta diberi petunjuk melakukan pembetulanya. Hasil pekerjaan peserta dibawa, menjadi milik peserta pelatihan. Bahkan beberapa peserta minta dibawakan lagi bahanbahan untuk dibawa selain bahan yang telah diberikan.

Kegiatan ditutup dengan memberikan pesan bahwa ketrampilan yang diberikan selain untuk dipakai/dimanfaatkan sendiri, juga agar dipergunakan untuk diajarkan kepada orang lain terutama di lokasi KKN.

\section{B. Hasil}

Hasil yang didapat dari pelatihan ini adalah semua peserta dapat menyelesaikan tugasnya dengan baik. Tentu saja dengan kecepatan dan kerapihan yang berbeda-beda. Akan tetapi seluruh peserta dapat menyelesaikan ketiga tugasnya dengan tuntas. Dilihat dari minat, peserta antusias mengikuti. Indikatornya adalah semua peserta megikuti kegiatan sampai acara selesai, tidak ada yang meninggalkan tempat di tengah acara. Bahkan peserta menginginkan diadakan lagi kegiatan serupa untuk ketrampilan yang berbeda. Dari hasil testimoni, peserta merasa bahwa kegiatan ini bermanfaat, dapat diteruskan, dan diperlukan baik untuk keperluan diri peserta ataupun untuk persiapan kkn. Peserta menghendaki agar di lokasi KKN dapat menularkan ketrampilan kepada masyarakat tempat mereka bertugas. Bahkan ada peserta yang sudah menyatakan akan mulai membuat dengan cara menyicil untuk souvenir hajatan.

Kendala yang dirasa oleh peserta adalah ketersediaan waktu untuk ikut pelatihan, beberapa orang digantikan oleh temanya karena sedang ada kuliah atau kegiatan lainya. Akan tetapi mereka yang tidak bisa ikut kegiatan umumnya merasa menyesal karena kegiatanya dirasakan mereka sangat menarik dan bermanfaat. 


\section{KESIMPULAN DAN SARAN}

\section{A. Kesimpulan}

Dengan dilaksanakanya kegiatan ini peserta memiliki ketrampilan yang bermanfaat untuk dirinya dan untuk masyarakat yang dibinanya. Pelaksana kegiatan juga berharap agar mendapat kesempatan untuk menyelenggarakan kegiatan sejenis yang lebih bervariasi dan dengan jumlah peserta yang lebih banyak. Peserta merasakan manfaat dan menginginkan untuk mengembangkan diri serta berharap ada pelatihan lain yang sejenis sebagai kelanjutanya.

Diharapkan pelatihan ini memberikan dampak terciptanya entrepreneur di kalangan

\section{DAFTAR PUSTAKA}

Aida Idris, 1983, Cara-cara Belajar yang Efisien, dalam Materi Dasar Program Bimbingan dan Konseling untuk Perguruan Tinggi; Psikologi Belajar, Proyek Normalisasi Kehidupan Kampus, Direktorat Jenderal Pendidikan Tinggi, Departemen Pendidikan dan Kebudayaan, Jakarta.

Amir Hamzah, Sulaeman, 1970, Media AudioVisual untuk Pengajaran, Penerangan dan Penyuluhan, P.T. Gramedia, Jakarta.

Arsyad, Azhar, 2002, Media Pembelajaran, Rajafindo Persada, Jakarta. peserta dan di kalangan masyarakat binaan. Target minimal adalah para peserta dapat menjadi instruktur yang mampu menularkan ketrampilan ke warga atau masyarakat di lokasi KKN.

\section{B. Saran}

LPM UNJ memberi kesempatan untuk melaksanakan kegiatan sejenis dan perlu diwujudkanya ketrampilan yang rutin antara lain dengan mendirikan pusat wirausaha. Atau pusat pelatihan ketrampilan. Semoga kegiatan ini memberi manfaat bagi pengembangan KKN dan masyarakat mandiri. Tuhan memberkati.

Dale, E., Audiovisual Method in Teaching (Third Edition), The Dryden Press, Holt, Renehart and Winson, Inc, New York.

Maman Achdiat, dkk.,1980, Teori Belajar Mengajar dan Aplikasinya dalam Program Belajar Mengajar, Proyek Pengembangan Pendidikan Guru (P3G), Departemen Pendidikan dan Kebudayaan, Jakarta.

Oemar Hamalik, 1982, Media Pendidikan, Alumni, Bandung,

http://www.perencanakeuangan.com/files/Faktor Penghasilan.html diambil tanggal 4/30/2012 jam 11:26 